\title{
Faktor-Faktor Yang Memengaruhi Kinerja Usaha Mikro Kecil Dan Menengah Bidang Fashion
}

\author{
Jesica Apriani dan Sarwo Edy Handoyo \\ Program Studi Manajemen, Fakultas Ekonomi dan Bisnis \\ Universitas Tarumanagara, Jakarta \\ Email: jessicapriani15@yahoo.com
}

\begin{abstract}
The purpose of this research is to determine the effect of entrepreneurial skills, market orientation, networking and entrepreneurial competence as mediating variables that affect the business performance of micro, small and medium-sized entreprises (SMEs) in the fashion sector at Tanah Abang Market. The samples used in this research were 100 respondents of micro, small and medium-sized entreprises owners at Tanah Abang Market by purposive sampling technique. This research used data analysis with the Partial Least Square (PLS) approach in the form of the Smart-PLS application version 3.0. The results of this research indicate that entrepreneurial skills, market orientation, and networks have a significant effect on performance which are mediated by entrepreneurial competencies and entrepreneurial competencies have a positive effect on performance.
\end{abstract}

Keywords: Entrepreneurial Skills, Market Orientation, Networking, Business Performa nce, Entrepreneurial Competence

Abstrak: Penelitian ini bertujuan untuk mengetahui pengaruh keterampilan kewirausahaan, orientasi pasar, jaringan dan kompetensi kewirausahaan sebagai variabel mediasi yang mempengaruhi kinerja usaha mikro kecil dan menengah pada bidang fashion di Pasar Tanah Abang. Sampel yang digunakan dalam penelitian ini sebanyak 100 responden pemilik usaha mikro kecil dan menengah di Pasar Tanah Abang dengan teknik purposive sampling. Penelitian ini menggunakan analisis data dengan pendekatan Partial Least Square (PLS) berupa aplikasi Smart-PLS versi 3.0. Hasil penelitian ini menunjukkan keteampilan kewirausahaan, orientasi pasar, dan jaringan memiliki pengaruh secara signifikan terhadap kinerja yang dimediasi oleh kompetensi kewirausahaan dan kompetensi kewirausahaan memiliki pengaruh positif terhadap kinerja.

Kata Kunci: Keterampilan Kewirausahaan, Orientasi Pasar, Jaringan, Kinerja, Kompetensi Kewirausahaan

\section{LATAR BELAKANG}

Dewasa ini, persaingan usaha mikro kecil menengah (UMKM) semakin ketat. Menurut data yang diperoleh dari Kementerian Koperasi dan UKM RI (www.ukmindonesia.id), tahun 2017, bahwa secara jumlah unit UMKM memiliki pangsa pasar sekitar 99,99\% (62.9 juta unit) dari total keseluruhan pelaku usaha di Indonesia (2017), sementara usaha besar hanya sebanyak 0,01\% atau sekitar 5400 unit. Usaha mikro menyerap sekitar 107,2 juta tenaga kerja $(89,2 \%)$, usaha kecil 5,7 juta $(4,74 \%)$, dan usaha menengah 3,73 juta $(3,11 \%)$; sementara usaha besar menyerap sekitar 3,58 juta jiwa. Dengan demikian gabungan UMKM 
menyerap sekitar 97\% tenaga kerja nasional, sementara usaha besar hanya menyerap sekitar $3 \%$ dari total tenaga kerja nasional.

Usaha mikro kecil dan menengah yang bergerak di bidang fashion saat ini memiliki peran dalam perekonomian. Pasar Tanah Abang adalah salah satu tempat yang memasarkan produk fashion dan merupakan pusat garmen terbesar di Asia Tenggara. Hal yang menjadi poin utama dalam persaingan pelaku usaha fashion di Tanah Abang adalah para pelaku usaha hanya menjual secara tradisional (jual-beli pada umumnya) dan hanya berorientasi pada hasil tanpa berorientasi pasar atau lainnya. Potensi dan peran UMKM harus terus dioptimalkan.

Keberhasilan suatu bisnis dapat dilihat melalui kinerja dari usaha tersebut. Kinerja merujuk pada tingkat pencapaian atau prestasi dari perusahaan dalam periode tertentu (Suci, 2009). Keterampilan kewirausahaan diidentifikasikan sebagai salah satu faktor yang mempengaruhi kinerja usaha. Keterampilan kewirausahaan adalah kegiatan atau pengetahuan untuk membangun dan mengoperasikan usaha dengan sukses secara kreatif (Linan dan Chen, 2009). Selain itu orientasi pasar merupakan peninjauan untuk menentukan sikap, arah, tempat, dan sebagainya yang tepat dan benar serta pandangan yang mendasari pikiran, perhatian atau kecenderungan (Sujatmiko, 2012:216). Perusahaan yang berorientasi pasar memiliki kinerja yang lebih baik daripada perusahaan yang tidak berorientasi pasar. Salah satu faktor penentu lainnya yang mempengaruhi keberhasilan dalam berwirausaha adalah adanya akses ke jaringan sosial (Zampetakis dan Kanelakis, 2010). Jaringan merupakan ikatan yang menghubungkan pelaku usaha dengan berbagai usaha dengan berbagai usaha, seperti partner usaha, teman, agen atau mentor untuk mendapatkan sumber daya yang dibutuhkan, misalnya informasi, uang dan dukungan moral para pelaku jejaring (George and Wood, 2001).

Keterampilan kewirausahaan, orientasi pasar dan jaringan tidak akan menunjukkan dampak yang berarti jika tidak ditunjang dengan kompetensi kewirausahaan dari para pelaku usaha. Menurut Al-Mamun et al (2016), kompetensi kewirausahaan didefinisikan sebagai kemampuan menggunakan sumber daya untuk meningkatkan kinerja usaha mikro. Berkat bantuan kompetensi kewirausahaan, pelaku usaha dapat menetapkan tujuan bisnis untuk perusahaan, dengan jelas menyatakan bagaimana tujuan akan dicapai, mengambil tindakan korektif dan langkah-langkah untuk mencapai tujuan (Solesvik, 2012). Penelitian Sanchez (2011) telah mengungkapkan bahwa dimensi kompetensi kewirausahaan ini memiliki pengaruh signifikan terhadap kinerja perusahaan. Penelitian mengenai competitive dan keterampilan kewirausahaan terhadap kinerja sebelumnya telah dilakukan oleh Rahim, Husni dan Yanti (2014). Penelitian tersebut menunjukkan bahwa dengan meningkatkan pengembangan sentra yang competitive advantage, kemampuan yang harus dimiliki oleh seorang pengelola IKM industri kreatif minang harus meningkatkan keterampilan usaha dan kemampuan mengelola keuangan, pemasaran serta produksi barang dan jasa, meningkatkan kemampuan inovasi, kewirausahaan, teknologi informasi dan berbagai sikap yang diperlukan untuk seorang pengusaha.

\section{KAJIAN TEORI}

Konsep yang sesuai untuk mendasari penelitian ini adalah teori RBV (resource based view). Teori RBV ini menjelaskan bahwa keunggulan kompetitif suatu perusahaan dihasilkan dari sumber daya uniknya dimana sumber daya tersebut dapat berupa keterampilan manajemen, proses organisasi, dan pengetahuan yang bernilai, unik, tidak dapat ditiru, dan tidak mudah tergantikan (Barney, 1991). Dalam penelitian ini, RBV juga 
menegaskan bahwa usaha mikro adalah entitas yang dapat bertahan dalam lingkungan sosial ekonomi dengan keterampilan kewirausahaan, orientasi pasar dan aktivitas jejaring yang meningkatkan kompetensi kewirausahaan serta kinerja usaha.

Keterampilan kewirausahaan berkaitan dengan kemampuan mengubah sesuatu menjadi sesuatu yang lebih baik sehingga seorang entrepreneur harus tetap berlandaskan pada kemampuannya menerapkan fungsi-fungsi manajemen agar usaha yang dijalankannya dapat berhasil dengan baik (Riyanti, 2003). Seorang wirausaha digambarkan berkaitan dengan pengambilan resiko, fungsi wirausaha termasuk supervisi, pengendalian, dan menyediakan arahan untuk perusahaan (Handriani, 2011).

Orientasi pasar merupakan budaya organisasi yang paling efektif dan efisien untuk mcnciptakan perilaku-perilaku yang dapat menghasilkan sesuatu yang terbaik bagi pelanggan (Narver and Slater, 1994). Pandangan serupa yang dikemukakan oleh Day (1988) menyatakan bahwa orientasi pasar mencerminkan kompetensi dalam memahami pelanggan, karena itu mempunyai peluang memberi kepuasan pada pelanggan sama halnya dengan kemampuannya dalam mengenali gerak-gerik pesaingnya.

Jaringan adalah hubungan saling percaya berdasarkan moral, dimana yang melatarbelakangi terbentuknya jaringan adalah norma bersama, adanya ikatan persaudaraan/ pertalian darah, adanya asas timbal balik (Fukuyama, 2005). Dengan demikian jaringan berperan dalam memperluas kerjasama dengan orang lain.

Kompetensi kewirausahaan adalah pengetahuan, sikap dan keterampilan yang terhubung satu dengan lainnya untuk dilatih dan dikembangkan agar menghasilkan kinerja terbaik dalam mengelola usahanya (Suryana, 2013). Seorang wirausahawan harus memiliki keunggulan yang merupakan kekuatan bagi dirinya dan usahanya serta harus memperbaiki kelemahannya agar menghasilkan keunggulan bersaing bagi usahanya. Selain itu kompetensi kewirausahaan juga merupakan kemampuan total seorang wirausahawan untuk menjalankan perannya dengan sukses (Ahmad et al, 2010).

Kinerja merujuk pada tingkat pencapaian ataupun prestasi dari perusahaan dalam periode waktu tertentu. Menurut Hasibuan (2002) menyatakan bahwa kinerja adalah suatu hasil kerja yang dicapai seseorang atau organisasi dalam melaksanakan tugas-tugas yang dibebankan kepadanya yang didasarkan atas kecakapan, pengalaman dan kesungguhan serta waktu. Kinerja sendiri dalam pekerjaan yang sesungguhnya tergantung pada kombinasi antara kemampuan, usaha dan kesempatan. Kinerja dapat diukur melalui melalui pertumbuhan penjualan dan porsi pasar (Ferdinand, 2000).

Kerangka pemikiran dalam penelitian ini ada pada Gambar 1. di bawah ini: 


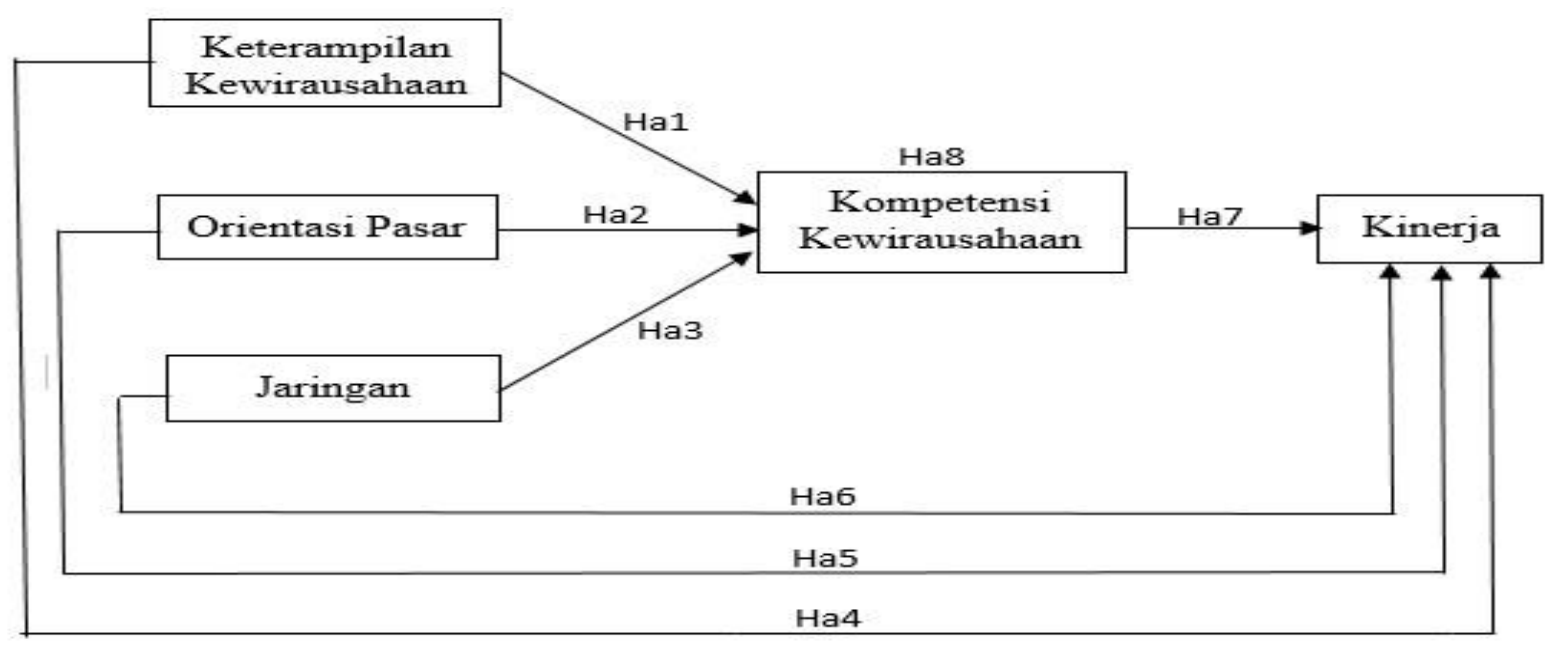

Gambar 1. Gambaran Pemikiran

Hipotesis dalam penelitian ini berdasarkan Gambar 1. di atas adalah:

Ha1: Keterampilan kewirausahaan memiliki pengaruh yang positif terhadap kompetensi kewirausahaan

Ha2: Orientasi pasar memiliki pengaruh yang positif terhadap kompetensi kewirausahaan.

Ha3: Jaringan memiliki pengaruh yang positif terhadap kompetensi kewirausahaan

Ha4: Keterampilan kewirausahaan memiliki pengaruh yang positif terhadap kinerja

Ha5: Orientasi pasar memiliki pengaruh yang positif terhadap kinerja

Ha6: Jaringan memiliki pengaruh yang positif terhadap kinerja

Ha7: Kompetensi kewirausahaan memiliki pengaruh yang positif terhadap kinerja

Ha8: Kompetensi kewirausahaan dapat memediasi keterampilan kewirausahaan, orientasi pasar dan jaringan terhadap kinerja

\section{METODOLOGI}

Penelitian yang dilakukan ini termasuk dalam kategori penelitian kuantitatif non eksperimental. Adapun hasil dari tujuan penelitian ini adalah menganalisis kemungkinan terjadinya hubungan sebab akibat dan pengaruh dari variabel-variabel penelitian melalui hipotesis yang dibangun, sehingga bisa disimpulkan penelitian ini merupakan penelitian kausal komparatif. Menurut Sekaran dan Bougie (2013) penelitian kausal komparatif merupakan penelitian yang membuktikan ciri-ciri dari teori serta menemukan pengaruh yang ilmiah atas sebab dan akibat dalam suatu variabel penelitian.

.Populasi penelitian ini adalah UMKM fashion di Pasar Tanah Abang. Teknik pemilihan sampel yang digunakan dalam penelitian ini adalah metode non-probability sampling, yaitu purposive sampling. Sampel yang digunakan dalam penelitian ini adalah pemilik UMKM fashion di Pasar Tanah Abang. Jumlah sampel yang dipilih sebanyak 100 responden. Penelitian ini mengumpulkan data pimer menggunakan kuesioner.

Analisis data yang digunakan dalam penelitian ini adalah pendekatan Partial Least Square (PLS) dengan menggunakan aplikasi software Smart-PLS versi 3.0. Evaluasi model dalam PLS terdiri dari dua tahap, yaitu evaluasi outer model dan evaluasi inner model. Evaluasi outer model yang digunakan dalam penelitian ini adalah Loading Factor, Cross Loading, Fornell-Larcker Criterion, Average Variances Exctracted, dan Composite 
Reliability. Sedangkan evaluasi inner model yang digunakan dalam penelitian ini adalah Path coefficient, Indirect Effect, R-Square (R2 ), Uji $f$-Square (f2 ), Uji Q-Square (Q2).

\section{HASIL ANALISIS DATA}

Berdasarkan evaluasi outer model, hasil analisis data validitas konvergen berupa outer loadings pada beberapa indikator dalam penelitian ini perlu dihilangkan seperti MO3, NE4, dan EP5 agar pernyataan lainnya menjadi valid. Nilai outer loadings setiap indikator memiliki nilai yang lebih besar dari 0,7 sehingga dinyatakan memiliki validitas yang tinggi dan nilai average variance extracted (AVE) diatas 0,5 maka seluruh variabel memiliki kelayakan evaluasi. Sedangkan hasil analisis data validitas diskriminan dapat dilihat dari nilai fornell-larcker criterion dimana seluruh variabel memiliki nilai akar AVE lebih besar dari korelasi antar konstruk dalam suatu model sehingga disimpulkan sudah memenuhi kelayakan evaluasi. Analisis cross loadings telah disimpulkan bahwa semua indikator variabel berhasil merefleksikan setiap variabelnya. Selanjutnya hasil uji reliabilitas dalam penelitian ini menggunakan composite reliability dan cronbach's alpha. Hasil uji composite reliability pada setiap variabel menunjukkan nilai diatas 0,7 dan hasil uji cronbach's alpha pada setiap variabel memili nilai diatas 0,6 sehingga data penelitian ini telah reliabel.

Berdasarkan evaluasi inner model, data yang sudah valid dan reliabel akan diolah menggunakan uji R square. Hasil pengujian R square dalam penelitian ini adalah variabel keterampilan kewirausahaan, orientasi pasar, dan jaringan memiliki pengaruh yang moderat terhadap kompetensi kewirausahaan yaitu sebesar 0,582 atau 58,2\% dan memiliki pengaruh yang moderat juga terhadap kinerja yaitu sebesar 0,703 atau $70,3 \%$. Dari hasil uji f square menyatakan bahwa seluruh variabel memiliki dampak pada nilai $\mathrm{R}$ square. Setelah itu uji $\mathrm{Q}$ square dengan metode blindfolding menjelaskan variabel keterampilan kewirausahaan, orientasi pasar, dan jaringan memiliki pengaruh yang besar terhadap kompetensi kewirausahaan dan kinerja. Kemudian hasil uji goodness of fit (GoF) dalam penelitian ini sebesar 0,666 yang menunjukkan tingkat kelayakan model penelitian ini tergolong besar. Melalui uji indirect effect, hasil variabel keterampilan kewirausahaan, orientasi pasar dan jaringan terhadap kinerja melalui kompetensi kewirausahaan sebagai variabel mediasi mempunyai nilai sebesar $0,008,0,015$, dan 0,049 secara berturut yang artinya memiliki prediktor positif.

\section{DISKUSI}

Berdasarkan hasil uji hipotesis dengan menggunakan metode bootstrapping maka didapatkan hasil penelitian sesuai Tabel 1. yaitu:

Tabel 1. Tabel Uji Hipotesis

\begin{tabular}{|l|c|c|}
\hline \multicolumn{1}{|c|}{ Variabel } & T-Statistik & P Values \\
\hline $\begin{array}{l}\text { Keterampilan Kewirausahaan -> } \\
\text { Kompetensi Kewirausahaan }\end{array}$ & 3,127 & 0,002 \\
\hline $\begin{array}{l}\text { Orientasi Pasar ->Kompetensi } \\
\text { Kewirausahaan }\end{array}$ & 4,112 & 0,000 \\
\hline $\begin{array}{l}\text { Jaringan ->Kompetensi } \\
\text { Kewirausahaan }\end{array}$ & 2,295 & 0,022 \\
\hline
\end{tabular}


Apriani dan Handoyo: Faktor-Faktor Yang Memengaruhi Kinerja Usaha...

\begin{tabular}{|c|c|c|}
\hline $\begin{array}{l}\text { Keterampilan Kewirausahaan -> } \\
\text { Kinerja }\end{array}$ & 2,399 & 0,019 \\
\hline Orientasi Pasar ->Kinerja & 2,312 & 0,021 \\
\hline Jaringan $->$ Kineja & 2,008 & 0,045 \\
\hline $\begin{array}{l}\text { Kompetensi Kewirausahaan -> } \\
\text { Kinerja }\end{array}$ & 3,805 & 0,000 \\
\hline
\end{tabular}

Berikut merupakan pembahasan mengenai hipotesis dalam penelitian ini:

Ha1: Keterampilan kewirausahaan memiliki pengaruh positif terhadap kompetensi kewirausahaan UMKM bidang fashion di Pasar Tanah Abang. Hipotesis ini telah mampu dibuktikan bahwa terdapat pengaruh positif variabel keterampilan kewirausahaan terhadap kompetensi kewirausahaan dengan hasil pengujiannya memiliki nilai T-Statistik sebesar 3,127 atau nilai P Values sebesar 0,002 sehingga Ha1 tidak ditolak karena T-Statistik lebih besar dari 1,96 atau P Values lebih kecil dari 0,05. Hal ini membuktikan penelitian terdahulu yang dilakukan Phelan dan Sharpley (2012) bahwa keterampilan kewirausahaan dan kompetensi kewirausahaan memiliki pengaruh. Pemilik usaha memerlukan berbagai keterampilan untuk mengembangkan kompetensi yang spesifik untuk mengelola suatu usaha dengan melakukan strategi khusus meliputi aspek pemasaran melalui teknologi atau online di Pasar Tanah Abang. Selain itu pemilik usaha juga harus handal dalam mengetahui kebutuhan pangsa pasar dikarenakan perputaran fashion sangatlah cepat agar tidak ketinggalan dengan pesaingnya. Persaingan usaha yang ketat di Pasar Tanah Abang mengharuskan pemilik usaha kreatif dalam operasi usaha sebab terdapat banyak sekali usaha sejenis di Pasar Tanah Abang.

Ha2: Orientasi Pasar memiliki pengaruh positif terhadap kompetensi kewirausahaan UMKM bidang fashion di Pasar Tanah Abang. Berdasarkan hasil pengujian maka variabel orientasi pasar terhadap kompetensi kewirausahaan memiliki nilai T-Statistik sebesar 4,112 atau nilai P Values sebesar 0,000 sehingga Ha2 tidak ditolak karena T-Statistik lebih besar dari 1,96 atau P Values lebih kecil dari 0,05. Jadi dapat disimpulkan bahwa variabel orientasi pasar memiliki pengaruh positif terhadap kompetensi kewirausahaan UMKM bidang fashion di Pasar Tanah Abang secara signifikan. Hal ini membuktikan penelitian terdahulu yang dilakukan Baker dan Sinkula (2009) bahwa orientasi pasar dapat memengaruhi kompetensi kewirausahaan untuk mengembangkan produk serta layanan untuk menargetkan pelanggan tertentu. Orientasi pasar mencerminkan kompetensi dalam memahami pelanggan, karena itu mempunyai peluang memberi kepuasan pada pelanggan dan sama halnya dengan kemampuannya dalam mengenali gerak gerik pesaingnya serta memiliki dasar perbaikan yang lebih cepat sehingga akan terlihat pada kesuksesan produk usahanya seperti keuntungan yang dihasilkan dari kompetensi kewirausahaan yang dilakukan dengan strategi yang dimiliki. Hasil dari implementasi strategi yang berdasarkan pada orientasi pasar, memungkinkan perusahaan beradaptasi dengan sukses terhadap perubahan lingkungan.

Ha3: Jaringan memiliki pengaruh positif terhadap kompetensi kewirausahaan UMKM bidang fashion di Pasar Tanah Abang. Berdasarkan hasil pengujian maka 
variabel jaringan terhadap kompetensi kewirausahaan memiliki nilai T-Statistik sebesar 2,295 atau nilai P Values sebesar 0,022 sehingga Ha3 tidak ditolak karena T-Statistik lebih besar dari 1,96 atau P Values lebih kecil dari 0,05. Jadi dapat disimpulkan bahwa variabel jaringan memiliki pengaruh positif terhadap kompetensi kewirausahaan UMKM bidang fashion di Pasar Tanah Abang secara signifikan. Hal ini membuktikan penelitian terdahulu yang dilakukan Baron dan Markman (2000) bahwa jaringan memiliki pengaruh terhadap kompetensi kewirausahaan UMKM. Jaringan ini merupakan salah satu cara agar pemilik usaha dapat melakukan interaksi sosial untuk memperoleh kredibilitas, mendapatkan akses atas informasi, meningkatkan kerjasama yang berasal dari pihak lainnya, dan dapat menjadi alat untuk menyalurkan bentuk kepercayaan yang lebih besar dari rekan kerja agar bisa bertahan dalam melaksanakan usaha berkelanjutan dengan strategi yang dilakukan di Pasar Tanah Abang.

Ha4: Keterampilan kewirausahaan memiliki pengaruh positif terhadap kinerja UMKM bidang fashion di Pasar Tanah Abang. Hipotesis ini telah dibuktikan bahwa terdapat pengaruh positif variabel keterampilan kewirausahaan terhadap kinerja yaitu memiliki nilai T-Statistik sebesar 2,399 atau nilai P Values sebesar 0,019 sehingga Ha4 tidak ditolak karena T-Statistik lebih besar dari 1,96 atau P Values lebih kecil dari 0,05. Hal ini membuktikan penelitian terdahulu yang dilakukan Lerner dan Almor (2002) sejalan dengan penelitian ini dimana hasil penelitiannya bahwa keterampilan kewirausahaan. memiliki pengaruh terhadap kinerja. Selain itu penelitian yang dilakukan Johnson Steve dkk, (2015) juga mendukung bahwa keterampilan kewirausahaan memiliki pengaruh yang positif terhadap kinerja. Berkaitan dengan usaha fashion, pemilik UMKM perlu memiliki keterampilan dalam mengelola usahanya. Keterampilan sebagai pemilik UMKM dapat dilihat dari bagaimana cara memecahkan masalah yang terjadi di Pasar Tanah Abang, serta seorang pemilik harus kreatif agar usaha fashion berbeda dengan saingan karena di Pasar Tanah Abang banyak usaha yang sejenis. Seorang pemilik usaha yang memiliki kreativitas, inovasi dan keterampilan maka akan sangat mempengaruhi keberlanjutan usaha dalam jangka panjangnya sehingga kinerja usahanya semakin baik. Hal ini akan mempertahankan eksistensi UMKM dan mampu bersaing secara berkelanjutan.

Ha5: Orientasi Pasar memiliki pengaruh positif terhadap kinerja UMKM bidang fashion di Pasar Tanah Abang. Berdasarkan hasil pengujian maka variabel orientasi pasar terhadap kinerja memiliki nilai T-Statistik sebesar 2,312 atau nilai P Values sebesar 0,021 sehingga Ha5 tidak ditolak karena T-Statistik lebih besar dari 1,96 atau P Values lebih kecil dari 0,05. Jadi dapat disimpulkan bahwa variabel orientasi pasar memiliki pengaruh positif terhadap kinerja UMKM bidang fashion di Pasar Tanah Abang secara signifikan. Hal ini membuktikan penelitian terdahulu yang dilakukan Ellis (2006) sejalan dengan penelitian ini dimana hasil penelitiannya bahwa orientasi pasar memiliki pengaruh positif terhadap kinerja. Orientasi pasar merupakan budaya usaha yang efekif dalam menciptakan perilaku penting untuk menciptakan nilai unggul bagi pelanggan serta kinerja dalam usaha. Semakin tinggi orientasi pasar yang dimiliki usaha maka kinerja usaha akan semakin tinggi karena usahanya akan memiliki keunggulan kompetitif dalam hal kualitas produk, kualitas pelayanan, ataupun inovasi produk. Kemudian usaha fashion yang memiliki tingkat orientasi pasar yang tinggi akan memiliki kinerja usaha yang baik karena usahanya memiliki kemampuan dalam memahami keinginan dan kebutuhan pelanggan sasaran. 
Ha6: Jaringan memiliki pengaruh positif terhadap kinerja UMKM bidang fashion di Pasar Tanah Abang. Berdasarkan hasil pengujian maka variabel jaringan terhadap kompetensi kewirausahaan memiliki nilai T-Statistik sebesar 2,008 atau nilai $\mathrm{P}$ Values sebesar -0,045 sehingga Ha6 tidak ditolak karena T-Statistik lebih besar dari 1,96 atau $\mathrm{P}$ Values lebih kecil dari 0,05. Jadi dapat disimpulkan bahwa variabel jaringan memiliki pengaruh positif terhadap kinerja UMKM bidang fashion di Pasar Tanah Abang secara signifikan. Hal ini membuktikan penelitian terdahulu yang dilakukan Hendriyanto (2015) sejalan dengan penelitian ini dimana hasil penelitiannya bahwa jaringan usaha memiliki pengaruh besar terhadap kinerja UMKM. Kinerja usaha dapat ditingkatkan dengan membangun jaringan sosial yang lebih luas. Semakin baik jaringan usaha yang dimiliki UMKM maka akan semakin meningkat kinerja usahanya. Pelaku UMKM pada bidang fashion harus dapat membina kerjasama dengan para pemasok, lembaga keuangan, tenaga kerja ataupun para perantara agar usahanya semakin berkembang.

Ha7: Kompetensi kewirausahaan memiliki pengaruh positif terhadap kinerja UMKM bidang fashion di Pasar Tanah Abang. Berdasarkan hasil pengujian maka variabel kompetensi kewirausahaan terhadap kinerja memiliki nilai T-Statistik sebesar 3,805 atau nilai P Values sebesar 0,000 sehingga Ha7 tidak ditolak karena T-Statistik lebih besar dari 1,96 atau P Values lebih kecil dari 0,05. Jadi dapat disimpulkan bahwa variabel kompetensi kewirausahaan memiliki pengaruh positif terhadap kinerja UMKM bidang fashion di Pasar Tanah Abang secara signifikan. Kesuksesan kewirausahaan ditentukan oleh kompetensi yang dimiliki seorang wirausaha dan akan mempengaruhi langsung keberhasilan kinerja usaha. Hal ini membuktikan penelitian terdahulu yang dilakukan Sarwoko et al (2013) bahwa semakin tinggi kompetensi kewirausahaan akan menyebabkan kinerja usaha semakin tinggi. Penelitian ini membuktikan bahwa kompetensi kewirausahaan menjadi sangat penting dimiliki oleh seorang pemilik UMKM karena merupakan sumberdaya yang bernilai, langka (unik), tidak dapat ditiru (tidak dapat dengan mudah dijual atau diperdagangkan), dan non-substitutable. Hal tersebut menjadi keunggulan dan menciptakan kinerja. Kinerja usaha dapat ditingkatkan dengan memiliki kepemimpinan dalam menjalankan usahanya, mampu bernegosiasi serta bertanggung jawab dan selalu dapat menyelesaikan masalah.

Ha8: Kompetensi kewirausahaan dapat memediasi pengaruh positif keterampilan kewirausahaan, orientasi pasar dan jaringan terhadap kinerja UMKM fashion di Pasar Tanah Abang. Hasil pengujian variabel keterampilan kewirausahaan, orientasi pasar dan jaringan terhadap kinerja melalui kompetensi kewirausahaan sebagai variabel mediasi mempunyai $\mathrm{P}$ Values sebesar 0,008, 0,015, dan0,049 secara berturut sehingga Ha8 tidak ditolak karena $\mathrm{P}$ Values lebih kecil dari 0,05. Artinya dapat disimpulkan bahwa variabel kompetensi kewirausahaan dapat memediasi variabel keterampilan kewirausahaan terhadap kinerja UMKM fashion di Pasar Tanah Abang secara signifikan. Hal ini juga sejalan dengan hasil penelitian yang telah dilakukan sebelumnya oleh Baron dan Kenny (1986) menyatakan bahwa adanya peran mediasi kompetensi kewirausahaan dari adanya pengaruh keterampilan kewirausahaan, orientasi pasar dan jaringan terhadap kinerja. 


\section{PENUTUP}

Berdasarkan hasil analisis dan pembahasan terhadap penelitian ini yang berjudul maka dapat ditarik kesimpulan sebagai berikut:

1. Terdapat pengaruh yang positif dan signifikan antara keterampilan kewirausahaan terhadap kompetensi kewirausahaan UMKM bidang fashion di Pasar Tanah Abang, Jakarta Pusat.

2. Terdapat pengaruh yang positif dan signifikan antara orientasi pasar terhadap kompetensi kewirausahaan UMKM bidang fashion di Pasar Tanah Abang, Jakarta Pusat .

3. Terdapat pengaruh yang positif dan signifikan antara jaringan terhadap kompetensi kewirausahaan UMKM bidang fashion di Pasar Tanah Abang, Jakarta Pusat.

4. Terdapat pengaruh yang positif dan signifikan antara keterampilan kewirausahaan terhadap kinerja UMKM bidang fashion di Pasar Tanah Abang, Jakarta Pusat.

5. Terdapat pengaruh yang positif dan signifikan antara orientasi pasar terhadap kinerja UMKM bidang fashion di Pasar Tanah Abang, Jakarta Pusat.

6. Terdapat pengaruh yang positif dan signifikan antara jaringan terhadap kinerja UMKM bidang fashion di Pasar Tanah Abang, Jakarta Pusat.

7. Terdapat pengaruh yang positif dan signifikan antara kompetensi kewirausahaan terhadap kinerja UMKM bidang fashion di Pasar Tanah Abang, Jakarta Pusat.

8. Terdapat pengaruh yang positif dan signifikan keterampilan kewirausahaan, orientasi pasar dan jaringan terhadap kinerja UMKM fashion di Pasar Tanah Abang, Jakarta Pusat dengan mediasi kompetensi kewirausahaan.

Berdasarkan hasil penelitian yang telah diperoleh, maka peneliti dapat memberikan beberapa saran yang dapat bermanfaat sebagai berikut:

1. Variabel penelitian ini hanya terbatas pada variabel keterampilan kewirausahaan, orientasi pasar, jaringan, kompetensi kewirausahaan yang berhubungan dengan kinerja sehingga untuk penelitian selanjutnya diharapkan ruang lingkup penelitian dapat diperluas lagi dengan menambah variabel penelitian lain selain variabel di atas.

2. Jenis kawasan dan jumlah populasi dalam penelitian ini hanya satu jenis yaitu UMKM bidang fashion di Pasar Tanah Abang. Untuk penelitian selanjutnya maka diharapkan untuk meneliti bidang lainnya serta menambah jumlah sampel dengan memperluas jangkauan wilayah penelitian untuk melihat bagaimana hasil penelitian yang bervariasi.

3. Indikator pada variabel keterampilan kewirausahaan, orientasi pasar, jaringan, dan kompetensi kewirausahaan yang berhubungan dengan kinerja sehingga untuk penelitian berikutnya diharapkan dapat menambah serta mengoreksi pernyataan penelitian yang akan dilakukan.

\section{DAFTAR PUSTAKA}

Ahmad, N.H., Ramayah, T., Wilson, C. and Kummerow, L. (2010). Is entrepreneurial competency and business success relationship contingent upon business environment? A study of Malaysian SMEs. International Journal of Entrepreneurial Behavior and Research, 16(3), 182-203.

Al-Mamun, A., Nawi, N.B.C. and Zainol, N.R.B. (2016). Entrepreneurial competencies and performance of informal micro-enterprises in Malaysia. Mediterranean Journal of Social Sciences, 7(3), 273-281. 
Baker, W.E. and Sinkula, J.M. (2009). The complementary effects of market orientation and entrepreneurial orientation on profitability in small businesses. Journal of Small Business Management, 47(4), 443-464.

Barney, J. (1991). Firm resources and sustained some competitive advantage. Journal of Management, 17(1), 99-121.

Baron, R.M. and Kenny, D.A. (1986). The moderator-mediator variable distinction in social psychological research: conceptual, strategic, and statistical consideration. Journal of Personality and Social Psychology, 51(6), 1173.

Baron, R. A. \& Markman, G. D. (2000). Beyond social capital: the role of social skills in entrepreneurs' success. Academy Management. Exec. 14, 1-15.

Day, G.S., and Wensley, R. (1988). Assessing Advantage: A Framework for Diagnosing Competitive Superiority. Journal of Marketing, 52.

Johnson Steve, Snowden Nick, Mukhuty Sumona, Fletcher Ben \& Williams Terry. (2015). Department for Business Innovation and Skill. Entrepreneurship Skills: Literature and Policy Review. Journal of Business Innovation and Skill, 236.

Ellis, P.D. (2006). Market orientation and performance: A meta-analysis and cross-national comparisons. Journal of Management Studies, 43(5), 1089-1107.

Ferdinand A.T. (2000). Marketing Management: Strategic Approach. Research Paper Series No.1.,Magister Management. Diponegoro University Publisher.

Fukuyama, Fracis. (2005). Guncangan Besar: Kodrat Manusia dan Tata Sosial Baru. Terj Masri Maris. Jakarta: Gramedia Pustaka Utama.

George, G., Wood, D. R. Jr, Khan, R. (2001). Networking Strategy of Boards : Implicationn for Small and Medium-Sized Enterprises. Entrepreneurship and Regional Development, 13(3), 269-285.

Handriani, Eka. (2011). Pengaruh Faktor Internal Eksternal, Entrepreneurial Skill, Strategi Dan Kinerja Terhadap Daya Saing UKM Di Kabupaten Semarang. Jurnal Dinamika Sosial Ekonomi, 7(1), 47- 69.

Hasibuan, Malayu S.P. (2002). Manajemen Sumber Daya Manusia. Bumi Aksara. Jakarta.

Hendriyanto, Asepta (2015). Analisis Pengaruh Jaringan Usaha dan Inovasi terhadap Kinerja UMKM. Jurnal Ilmu Manajemen dan Akuntansi Terapan (J'MAT), 6(1).

Lerner, M. and Almor, T. (2002). Relationships among strategic capabilities and the performance of women-owned small ventures. Journal of Small Business Management, 40(2), 109-125.

Linan, F., \& Chen, Y.W. (2009). Development and cross-cultural application of a specific instrument to measure entrepreneurial intentions. Entrepreneurship Theory and Practice, 33(3), 593-617.

Narver, J.C. and Slater, S.F. (1994). Creating a Market Orientation, Journal of Market- Focused Management, 2(3).

Phelan, C. and Sharpley, R. (2012). Exploring entrepreneurial skills and competencies in farm tourism. Local Economy: The Journal of the Local Economy Policy Unit, 27(2), 103-118.

Rahim Rida, Husni Tafdil, Yanti. (2014). Pengembangan Model Sentra Industri Kreatif Motif Kerajinan Minang Melalui Adaptability IKM, Inovasi, Kewirausahaan dan Keunggulan Kompetitif. Universitas Andalas.

Riyanti, Benedicta Prihatin Dwi. (2003). Kewirausahaan dari Sudut Pandang Psikologi Kepribadian. Jakarta: Penerbit Gramedia Widiasarana Indonesia.

Sanchez J. (2011). The Influence of Entrepreneural Competencies on Small Firm Performance. Revista Latinamericana de Psicologia, 44(2), 165-177.

Sarwoko E, Surachman, Armanu, \& Hadiwidjojo DJ. (2013). Entrepreneurial Characteristics and Competency as Determinants of Business Performance in SMEs. IOSR Journal of Business and Management (IOSR-JBM), 7(3), 31- 38.

Uma Sekaran, R. B. (2013). Business Research Method. New Jersey: John Wiley \& Sons, Inc. 
Solesvik, M. Z. (2012). Entrepreneurial Competencies in Emerging Context. 17th Nordic Conference on Small Business Research, Helsinki, 23-25 May.

Suci, Rahayu Puji. (2009). Peningkatan Kinerja Melalui Orientasi Kewirausahaan, Kemampuan Manajemen, Dan Strategi Bisnis (Studi Pada Industri Kecil Menengah Bordir Di Jawa Timur) (Jurnal). Malang: Universitas Widyagama.

Sujatmiko, Eko. (2012). Kamus Teknologi Informasi dan Komunikasi. Surakarta:PT. Aksarra Sinergi Media.

Suryana. (2013). Kewirausahaan (Kiat dan Proses menuju Sukses). Edisi IV. Salemba Empat. Jakarta.

Zampetakis, L.A. and Kanelakis, G. (2010). Opportunity entrepreneurship in the rural sectoru evidence from Greece. Journal of Research in Marketing and Entrepreneurship, 12(2), 122142.

(www.ukmindonesia.id, 24 July 2018) 